\title{
Psychological distress in women with recurrent spontaneous abortion: A case-control study
}

\section{Rekürren spontan abortus yapan kadınlarda psikolojik sıkıntı: Bir olgu kontrol çalışması}

\author{
(D) Hajar Adib-Rad ${ }^{1}$, (1) Zahra Basirat ${ }^{1}$, (1) Mahbobeh Faramarzi ${ }^{1}$, (1) Amrollah Mostafazadeh², (D) Ali Bijani ${ }^{3}$ \\ ${ }^{1}$ Babol University of Medical Sciences, Institute of Health Research, Infertility and Reproductive Health Research Center, Babol, Iran \\ ${ }^{2}$ Babol University of Medical Sciences, Institute of Health Research, Cellular and Molecular Biology Research Center, Babol, Iran \\ ${ }^{3}$ Babol University of Medical Sciences, Institute of Health Research, Social Determinants of Health Research Center, Babol, Iran
}

\begin{abstract}
Objective: The aim of the present study was to evaluate psychological problems in women with recurrent spontaneous abortion (RSA).

Materials and Methods: In this case-control study, 115 women with RSA were assigned to the case group and 240 non-pregnant women comprised the control group. The revised version of the Symptom Checklist-90 (SCL-90-R) and the Intolerance of Uncertainty scale (IUS) were used for assessing mental health problems. Results: The results showed that the mean Global Severity Index (GSI) of the SCL-90-R and the IUS scores in the case and control groups were 109.10 \pm 59.85 and $68.91 \pm 22.17$, and $82.98 \pm 52.99$ and $59.19 \pm 23.01$, respectively. GSI was the strongest predictor of RSA [odds ratio (OR) $=6.43$; $95 \%$ confidence interval $(\mathrm{CI})$ : $3.52-$ 11.72]. The chance estimate of RSA was approximately 2.1 times higher in women in rural areas (OR=2.07; 95\% CI: 1.16-3.69), and 2 times higher at 12 months after the last pregnancy (OR=1.99; 95\% CI: 1.42-2.78).

Conclusion: Psychological problems are greater after RSA. Therefore, it is suggested that the treatment of RSA emphasizes psychological counseling and psychological management.
\end{abstract}

Keywords: Recurrent spontaneous abortion, anxiety, depression, intolerance of uncertainty

$\ddot{\mathrm{O} z}$

Amaç: Mevcut çalışmanın amacı, rekkürren spontan abortus (RSA) yapan kadınlardaki psikolojik problemleri değerlendirmektir.

Gereç ve Yöntemler: Bu olgu kontrol çalışmasında, 115 RSA'lı kadın olgu grubuna ve 240 gebe olmayan kadın da kontrol grubuna dahil edilmiștir. Semptom Kontrol Listesi'nin revize edilmiş versiyonu (SCL-90-R) ve Belirsizlik İntoleransı ölçeği (IUS) mental sağlık problemlerinin değerlendirilmesi için kullanılmıştır.

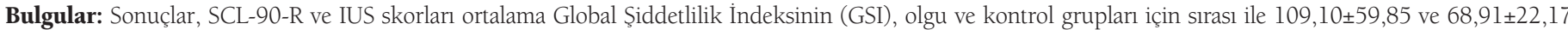

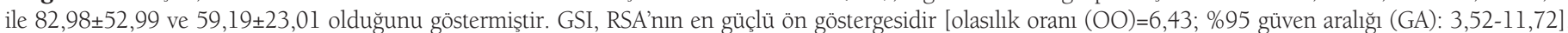
RSA'nın şans tahmini kırsal kesimdeki kadınlarda yaklaşık 2,1 kat daha yüksektir (OO=2,07; \%95 GA=1,16-3,69) ve en son gebelikten 12 ay sonra da 2 kat daha yüksektir $(\mathrm{OO}=1,99 ; \% 95 \mathrm{GA}=1,42-2,78)$

Sonuç: RSA sonrasında psikolojik problemler daha büyüktür. Bu nedenle, RSA tedavisinin psikolojik danışmayı ve psikolojik yönetimi vurgulaması önerilir. Anahtar Kelimeler: Rekürren spontan abortus, anksiyete, depresyon, belirsizlik intoleransı

\section{Introduction}

Infertility and recurrent spontaneous abortion (RSA) are two challenging issues in the field of obstetrics and gynecology $y^{(1,2)}$. The perception of infertility has received great attention as a psychological problem ${ }^{(3,4)}$. It is considered as one of the numerous difficulties that patients should receive the best services in the diagnosis, treatment, and psychological support ${ }^{(5)}$. RSA is one of the most important problems related to infertility. It is defined as two or more consecutive pregnancy losses ${ }^{(6)}$. According to the American Society for Reproductive Medicine Practice Committee, RSA includes clinical abortion that is ascertained by

PRECIS: The loss of a desired pregnancy is a considerable negative life occurrence, and this problem may cause important physical and psychological distress.

Address for Correspondence/Yazışma Adresi: Zahra Basirat, MD,

Babol University of Medical Sciences, Institute of Health Research, Infertility and Reproductive Health Research Center, Babol, Iran

Phone: +98 1112199595 E-mail: basiratzahra@yahoo.com ORCID ID: orcid.org/0000-0002-3191-1355

Received/Gelis Tarihi: 13.02.2019 Accepted/Kabul Tarihi: 09.06.2019

${ }^{\oplus}$ Copyright 2019 by Turkish Society of Obstetrics and Gynecology

Turkish Journal of Obstetrics and Gynecology published by Galenos Publishing House. 
ultrasound or histology ${ }^{(7)}$. RSA occurs due to genetic or uterine problems, thrombophilia, autoimmune endocrine diseases, infections, and several environmental factors ${ }^{(8)}$. Further, all cases of unknown infertility are often imputed to psychological causes $^{(9)}$. The loss of a desired pregnancy is a considerable negative life occurrence, and this problem may cause notable physical and psychological distress ${ }^{(10)}$. Pregnancy loss is related with anxiety and distress, especially in women who experience $\mathrm{RSA}^{(11)}$. The prevalence of depression in abortion ranges from $15 \%$ to $33 \%{ }^{(12,13)}$. In one study, researchers surveyed psychological adjustment to abortion and found that $50 \%$ of women with a history of abortion experienced depression and anxiety for several months ${ }^{(14)}$. Abortion may cause intolerance of uncertainty (IU) in women, which is a cognitive bias from a series of negative beliefs about uncertainty and its implications. In IU, a person perceives information in unclear circumstances and responds to it with a set of cognitive, emotional, and behavioral reactions ${ }^{(15)}$. Anxiety symptoms start immediately after abortion and continue until nearly 4-6 months later ${ }^{(16)}$. Additionally, while waiting for the next pregnancy, there is usually a high level of uncertainty and anxiety, which reduces the person's ability to tackle problems ${ }^{(17)}$. According to the recommendations of the World Health Organization, women should wait for 6 months after an abortion and before attempting to become pregnant again ${ }^{(18)}$. However, about 50 to $80 \%$ of women become pregnant again soon after the abortion, and the next pregnancy is at risk of causing anxiety and depression ${ }^{(19)}$. Therefore, it is unclear if past RSA may be associated with depression or anxiety experienced by women. Thus, the future consequences of an RSA are unknown. Sham et al. ${ }^{(20)}$ reported no enhanced risk of psychiatric symptoms in subsequent abortion. Nevertheless, another study revealed that depression and anxiety after an abortion were significant predictors of symbolic anxiety and depression in the first trimester of the subsequent pregnancy ${ }^{(21)}$. Additionally, pregnancy loss may cause women to be concerned about the success of the next pregnancy ${ }^{(22)}$. Thus, owing to the impact of RSA, the diagnosis and management of anxiety and depression during the pregnancy after an abortion is as crucial as that of psychological distress during pregnancy ${ }^{(23)}$. Psychological support, also known as "tender loving care", is considered essential for women who experience unexplained $\mathrm{RSA}^{(24)}$. Women without social support are at a higher risk of exhibiting psychological morbidity or symptoms after a pregnancy loss or infertility ${ }^{(25,26)}$. RSA is a distressing situation for infertile couples and frustrating for physicians. Accordingly, the European Society of Human Reproduction and Embryology and the Royal College of Obstetricians and Gynaecologists recommended offering supportive care during future pregnancies for women with unexplained RSA ${ }^{(27)}$. Many studies have been performed on depression in infertility but there are few studies on distress in RSA. Also, studies on the impact of psychological issues in RSA have reported conflicting findings. Therefore, the present study was conducted in Babol
University of Medical Sciences in northern Iran to determine the impact of psychological problems on RSA.

\section{Materials and Methods}

\section{Participants and procedure}

This study was approved by the Research Ethics Committee of the Babol University of Medical Sciences (ID: MUBABOL. REC.2015.42). This case-control study was conducted from May 2015 to February 2017 in Babol, Iran. All patients signed the free and informed consent form. In total, 120 women with RSA were referred to the research center because of infertility. The women in the RSA group had primary infertility and had no children. RSA was defined as having two or more consecutive abortions in the first trimester of pregnancy. Out of those referred, 5 women were excluded owing to incomplete questionnaires, and the final case sample comprised 115 women. All women with known probable etiologies for RSA and known mental illnesses were excluded from the study. The inclusion criteria for the patients with RSA included having experienced at least two consecutive idiopathic abortions of a desired pregnancy with a sexual partner; regular menstruation; no history of polycystic ovary syndrome; normal gynecologic status; anatomy, and karyotype; normal levels of the antiphospholipid antibody, anti-nuclear antibody, anti-cardiolipin antibody, anti-thrombin 3, lupus anti-coagulant, homocysteine, protein S, protein C, factor V Leiden, anti-thyroid peroxidase, thyroid hormones, and prolactin; and normal spermogram and karyotype of the sexual partner. Women without RSA who were referred to primary healthcare centers were selected as control subjects. These 265 healthy, non-pregnant women with at least one living child had no history of infertility, previous abortion, preterm deliveries, or stillbirths. Among them, 25 women were excluded from the study due to failure to complete the questionnaire, and a final sample of 240 women was used as the control group. The case and control groups were evaluated from three months to one year after abortion or childbirth, respectively.

\section{Demographics and questionnaires}

All participants completed the sociodemographic information questionnaire, the revised version of the Symptom Checklist-90 (SCL-90-R), and the Intolerance of Uncertainty scale (IUS). For both groups, we collected information on the couple's age, level of education, body mass index (BMI), occupation, residence, home ownership status, satisfaction with income, and gravidity and time passed since the last pregnancy. The SCL-90-R is one of the most widely used symptom questionnaires in the field of psychiatry. This self-reported questionnaire evaluates the following 9 symptoms: somatization, sensitivity, obsessivecompulsive disorder, aggression, phobic anxiety, paranoia, depression, anxiety, and psychotic tendency. The total score is evaluated as the Global Severity İndex (GSI). This checklist comprises 90 questions with 5 response options $(0=$ not at all, 
$1=$ a little bit, $2=$ moderately, $3=$ quite a bit, $4=$ extremely $)^{(28,29)}$. The IUS assesses cognitive bias that changes perceptions, interpretations, and individual reactions in uncertain situations based on the levels of cognitive, emotional, and behavioral responses in such situations. IU is defined as the predisposition to react negatively to an uncertain event or situation, independent of its probability of occurrence and of its associated consequences. IU reflects beliefs about the necessity of being certain, the capacity to cope with unpredictable change, and about adequate functioning in situations that are inherently ambiguous $^{(30)}$. IUS is correlated with psychological problems such as anxiety and depression, but infertility and abortion, especially recurrent abortion, is a specific situation with high frequency of uncertainty events. Infertility is uncertainty as a diagnosis, uncertainty as successful treatments and uncertainty as future outcomes. Also, recurrent abortion is full of uncertainty conditions, such as uncertainty as to the cause and if related with disease, uncertainty regarding future pregnancy and future outcomes. The IUS is a 27 -item questionnaire that assesses incompatible beliefs that lead to IU . Responses to items are made using a 5 point Likert scale (not at all, somewhat, medium, high, very high). The internal consistency of the scale was $\alpha=0.91$, and its reliability was $78 \%$ in a previous study ${ }^{(15)}$. This scale classifies the nature of worry experienced by healthy into the following four categories: bearing down on ambiguous situations, positive beliefs about worry, cognitive avoidance, and negative problem orientation ${ }^{(31)}$.

\section{Statistical Analysis}

Data analyses were performed using the Statistical Package for the Social Sciences (SPSS) 22.0 software package. The differences in sociodemographic characteristics and psychological distress between women with and without RSA were determined using the t-test and chi-square test. Analysis of variance (ANOVA) and the Tukey's test were used to examine differences in psychological distress at 1-6, 7-12, and >12 months after abortion and delivery. Additionally, the predictive factors of RSA (age, GSI, education, time passed since last pregnancy, occupation, residence, and income) were examined using multiple logistic regression analysis. Also, Pearson correlation analysis was used to identify the significant relationship of IUS and SCL-90-R. A p value of less than 0.05 was considered significant.

\section{Results}

The sociodemographic characteristics of the participants are presented in Table 1. There was no significant difference between the case and control groups regarding BMI, occupation, level of education, husband's age and level of education, satisfaction with income, and home ownership status (Table 1). The mean global GSI on the SCL-90-R score in women with and without RSA were $109.10 \pm 59.85$, and $82.98 \pm 52.99$, respectively $(\mathrm{p}=0.0001)$. Also, the mean IUS score in women with and without RSA was $68.91 \pm 22.17$, and $59.19 \pm 23.01$, respectively $(\mathrm{p}=0.0001)$. There was a significant difference in location between the two groups. Therefore, we examined if their psychological distress varied based on location. Table 2 shows the mean and standard deviation on all subscales of the SCL-90-R and the IUS for the recognition of prior learning and control groups. It was observed that in the case group, the scores were higher in rural populations as compared with those in urban populations. In contrast, in the control group, the scores in rural populations were lower than those in urban populations ( $\mathrm{p}=0.0001)$. ANOVA and Tukey's test were used to assess differences in psychological distress at 1-6, 7-12, and $>12$ months after pregnancy loss and birth. In the group without RSA (control group), scores on all psychological distress subscales reduced significantly between 1-6 months to $>12$ months after birth $(p=0.0001)$. However, in the RSA group, mental health problems remained stable even after 12 months since abortion. The Tukey's test results for the different time periods since the last pregnancy are summarized in Table 3. Table 4 shows the predictive factors of RSA based on the findings of multiple logistic regression analysis in the first stage. Seven factors including age, GSI, education, time passed since last pregnancy, occupation, residence, and satisfaction with income were included in the analysis. The odds ratio (OR) of the GSI was good for RSA before the adjustment $[\mathrm{OR}=3.48$; $95 \%$ confidence interval $(\mathrm{CI})=(2.10-5.77), \mathrm{p}<0.001]$ and this association was strengthened by considering other factors. The adjusted ORs for factors that were significantly associated with the chance of RSA are summarized in Table 4. Using this method, we excluded the variable of having age over 30 years in the second stage, jobs in the third stage, and satisfaction with income in the fourth stage, and only GSI [OR=6.43; 95\% $\mathrm{CI}=(3.52-11.72)]$, time passed since last pregnancy $(\mathrm{OR}=1.99$; 95\% CI $=1.42-2.78)$, education $(\mathrm{OR}=0.49 ; 95 \% \mathrm{CI}=0.50-$ 1.84), and residence (OR=2.07; 95\% CI=1.16-3.69) remained in the model. After adjusting for other variables, the multiple logistic regression analysis showed that the chance of RSA was higher in women living in rural areas as compared with those living in urban areas $(\mathrm{p}=0.013)$, and in people with an educational level of high school diploma or less as compared with their counterparts $(\mathrm{p}=0.026)$. Also, Pearson correlation analysis showed a significant relationship of IUS with SCL-90-R $(\mathrm{r}=0.650, \mathrm{p}<0.001)$.

\section{Discussion}

Recurrent abortion and the postpartum period are serious time points for women ${ }^{(32,33)}$. In this study, we found that the incidence of psychological disorders was higher in women with recurrent abortions, as evident from their higher scores on the SCL-90-R and IUS as compared with those of the control group. These results are in agreement with those of the Kolte et al. ${ }^{(34)}$ who revealed that $8.6 \%$ of women with RSA, versus $2.2 \%$ of healthy women had moderate or severe 
depression. In another study that examined the psychological adjustment in couples with a history of recurrent miscarriage, the results showed that, according to Beck Depression index scores, women presented significantly higher levels of anxiety and depression as compared with men. Further, 25\% of the women, versus $3.9 \%$ of the men, exhibited a high level of state anxiety as assessed using the State-Trait Anxiety Inventory (STAI-S $\geq 55$ ), and $23.7 \%$ of the women, versus $5.3 \%$ of the men, exhibited a high level of trait anxiety (STAI-T $\geq 55)^{(35)}$. In Sugiura-Ogasawara et al.'s ${ }^{(29)}$ study, 305 women with a history of recurrent abortion first completed a set of questionnaires including the K6 (a new screening instrument for anxiety and mood disorders) and the SCL-90-R. Subsequently, 170 women received a description about a successful live birth, after which they answered the questionnaires again. The results showed that, in the first survey, $15.4 \%$ of the women exhibited anxiety or depression. Additionally, high scores on the K6 were correlated with high scores on all the subscales of the SCL-
90-R. Further, in the 170 women who received a description of a successful live birth, all scores in the second survey were significantly lower as compared with the first survey, indicating an improvement in their depression levels ${ }^{(29)}$. In another study, results showed that a high score on the IUS were associated with an increased risk of opposing behaviors ${ }^{(36)}$. In addition, Carleton et al. ${ }^{(37)}$ reported that IUS scores in women with social anxiety disorder were higher than those in women with panic disorder $(p<0.01)$. Furthermore, in one study on 151 members with primary social anxiety disorder, their IUS scores were evaluated before and after 12 weeks of cognitive behavioral therapy. The findings showed significantly lower scores after treatment ${ }^{(38)}$. These findings indicate that anxiety is higher in infertile women. Infertility and recurrent abortion can lead to a substantial amount of pressure on women. These women do not recover spontaneously, and they need appropriate diagnostic services, care, and psychological intervention. In our study, the control group exhibited a significant reduction in

Table 1. Sociodemographic characteristics in population study

Characteristic

Age (mean \pm SD, year $)$

Husband's age (mean \pm SD, year)

$\operatorname{BMI}\left(\mathrm{kg} / \mathrm{m}^{2}\right)$

Occupation (n, \%)

Employed

Housewife

Level of education (n, \%)

Diploma

College

Husband's education (n, \%)

Under the diploma

Diploma

College

\section{Residence (n, \%)}

Urban

Rural

\section{Satisfaction with income (n, \%)}

Good (very satisfactory)

Moderate (satisfactory)

Weak (unsatisfactory)

Home ownership status (n, \%)

Private

Rental

Gravidity (mean \pm SD)
Under the diploma

\section{With RSA ( $n=115) \quad$ Without RSA $(n=240) \quad$ p value}

$\begin{array}{lll}30.66 \pm 5.30 & 29.29 \pm 4.85 & 0.020 \\ 33.99 \pm 5.83 & 33.62 \pm 5.22 & 0.552 \\ 26.85 \pm 4.05 & 26.72 \pm 4.17 & 0.782\end{array}$

$\begin{array}{lll}12(46.2) & 14(53.8) & 0.119\end{array}$

$103(31.3) \quad 226(68.7)$

$35(38.9) \quad 55(61.1)$

0.0001

$37(25.7) \quad 107(74.3)$

$43(35.5) \quad 78(64.5)$

$48(35.6) \quad 87(64.4)$

$30(27.5) \quad 79(72.5)$

$37(33.3) \quad 74(66.7)$

0.398

\section{$63(27.6)$ \\ $52(40.9)$}

$165(72.4)$
$75(59.1)$

0.010

$31(26.1) \quad 88(73.9)$

$70(37.2) \quad 118(62.8)$

$14(29.2) \quad 34(70.8)$

0.109

$\begin{array}{ll}64(31.7) & 138(68.3) \\ 51(33.3) & 102(66.7) \\ 2.64 \pm 0.92 & 1.52 \pm 0.50\end{array}$

0.742

$2.64 \pm 0.92$

$1.52 \pm 0.50$

Time passed since last pregnancy (n, \%)

1-6 months

7-12 months

$33(21.9) \quad 118(78.1)$

$38(41.8) \quad 53(58.2)$

$44(38.9) \quad 69(61.1)$

0.073

$>12$ months

SD: Standard deviation, BMI: Body mass index, RSA: Recurrent spontaneous abortion, $\dagger$ The data were assessed using chi-square and t-tests, 
their scores on all subscales in psychology from 1-6 months to $>12$ months after birth; however, the same women with RSA remained stable even 12 months after abortion. Broen et al. ${ }^{(39)}$ showed that women who experienced a spontaneous abortion exhibited more distress between 10 days and 6 months after the miscarriage. Kagami et al. ${ }^{(35)}$ reported that depression increased from $8.9 \%$ in the $\leq 3$ month period after miscarriage, and to $9.1 \%$ in the $>3$ month period; whereas, anxiety decreased after 3 months. In contrast to our study, Kolte et al. ${ }^{(34)}$ stated that, in
$44.4 \%$ of women whose last pregnancy loss was six months ago, the time since abortion was not related to psychological factors. In another study, the effect of duration since last recurrent abortion was not evaluated with regard to mental health ${ }^{(12)}$. The above results indicate that abortion and mental health problems resulting from RSA may sustain even after one year. Therefore, psychological counseling and intervention are necessary for patients with RSA. In our study, the predictors of RSA included GSI, time passed since last pregnancy, education, and

Table 2. Psychological distress according to the residence in two groups

\begin{tabular}{|c|c|c|c|c|c|c|}
\hline \multirow[b]{2}{*}{ Psychological scores } & \multicolumn{2}{|l|}{ With RSA } & \multirow[t]{2}{*}{$\mathrm{p}$ valuet } & \multicolumn{2}{|l|}{ Without RSA } & \multirow[t]{2}{*}{$\mathrm{p}$ value $t$} \\
\hline & $\begin{array}{l}\text { Urban } \\
(n=63)\end{array}$ & $\begin{array}{l}\text { Rural } \\
(n=52)\end{array}$ & & $\begin{array}{l}\text { Urban } \\
(n=165)\end{array}$ & $\begin{array}{l}\text { Rural } \\
(n=75)\end{array}$ & \\
\hline \multicolumn{7}{|l|}{ SCL-90-R $($ mean \pm SD $)$} \\
\hline Somatization & $1.03 \pm 0.60$ & $1.25 \pm 0.84$ & 0.104 & $1.08 \pm 0.68$ & $0.56 \pm 0.33$ & 0.0001 \\
\hline OCD & $1.34 \pm 0.62$ & $1.53 \pm 0.76$ & 0.138 & $1.38 \pm 0.72$ & $0.59 \pm 0.38$ & 0.0001 \\
\hline Anxiety & $1.02 \pm 0.56$ & $1.39 \pm 0.98$ & 0.017 & $1.04 \pm 0.75$ & $0.70 \pm 0.50$ & 0.0001 \\
\hline Hostility* & $1.08 \pm 0.69$ & $1.45 \pm 0.92$ & 0.021 & $1.11 \pm 0.72$ & $0.57 \pm 0.51$ & 0.0001 \\
\hline Phobic anxiety & $0.60 \pm 0.56$ & $1.03 \pm 0.83$ & 0.002 & $0.72 \pm 0.59$ & $0.41 \pm 0.31$ & 0.0001 \\
\hline Paranoid ideation & $1.27 \pm 0.69$ & $1.50 \pm 0.86$ & 0.121 & $1.33 \pm 0.73$ & $0.66 \pm 0.48$ & 0.0001 \\
\hline Psychoticism & $0.69 \pm 0.52$ & $1.13 \pm 0.98$ & 0.005 & $0.77 \pm 0.63$ & $0.35 \pm 0.30$ & 0.0001 \\
\hline
\end{tabular}

SD: Standard deviation, SCL-90-R: Symptom Checklist-90-Revised, RSA: Recurrent spontaneous abortion, OCD: Obsessive-compulsive disorder, GSI: Global severity index, IUS: Intolerance of Uncertainty Scale, *Aggression and irritability, $\uparrow$ The data were assessed using t-tests

Table 3. Trend of psychological distress after pregnancy loss/birth

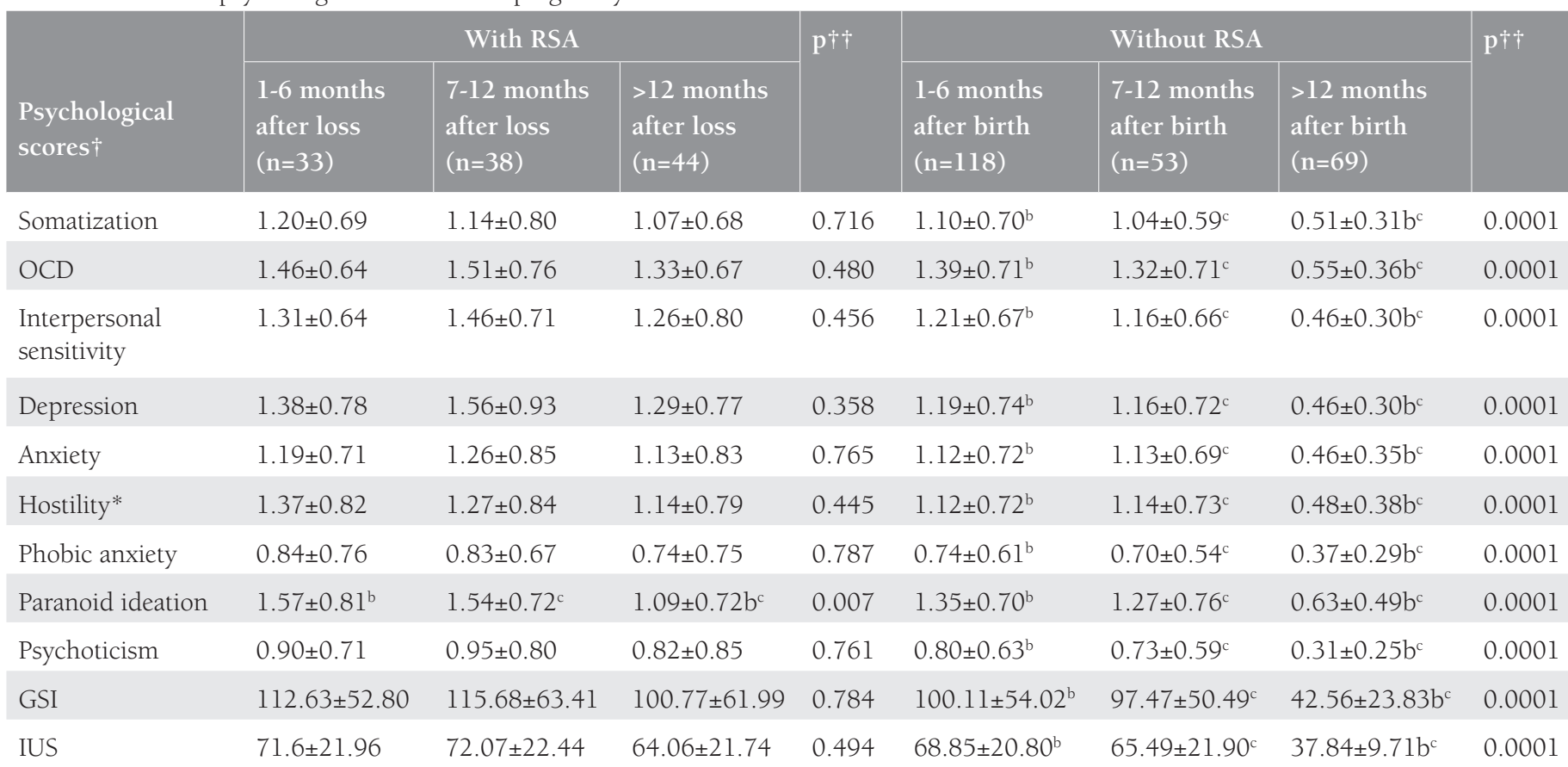

RSA: Recurrent spontaneous abortion, OCD: Obsessive-compulsive disorder, GSI: Global severity index, IUS: Intolerance of Uncertainty scale, ${ }^{a}$ Tukey test significantly in 1-6 months and 7-12 months after loss/birth, ${ }^{b}$ Tukey test results 1-6 months and >12 months after loss/birth, 'Tukey test results 7-12 months and >12 months after loss/birth, *Aggression and irritability, $\dagger$ Data are presented as mean \pm standard deviation, $\uparrow \dagger$ The data were assessed using $t$-tests 
Table 4. Predictive factors of recurrent spontaneous abortion in the multiple logistic regression analysis in the first stage

$\begin{array}{llll}\text { Variable } & \text { OR } & 95 \% \text { CI } & \text { p value† } \\ \text { Age }>30 \text { years } & 1.27 & 0.75-2.24 & 0.398 \\ \text { GSI }>63 & 6.05 & 3.27-11.18 & 0.0001 \\ \begin{array}{l}\text { Time passed since last } \\ \text { pregnancy }>12 \text { months }\end{array} & 1.87 & 1.29-2.70 & 0.001 \\ \begin{array}{l}\text { Education } \\ \text { Under the diploma (R) }\end{array} & & & \\ \begin{array}{l}\text { Diploma } \\ \text { College }\end{array} & 0.47 & 0.25-0.89 & 0.022 \\ \begin{array}{l}\text { Occupation } \\ \text { Residence }\end{array} & 0.95 & 0.47-1.90 & 0.894 \\ \begin{array}{l}\text { Satisfaction with income } \\ \text { High (R) }\end{array} & 2.13 & 0.23-1.73 & 0.379 \\ \begin{array}{l}\text { Middle } \\ \text { Low }\end{array} & 1.60 & 0.88-2.90 & 0.1918 \\ & 1.11 & 0.48-2.61 & 0.795\end{array}$

OR: Odds ratio, CI: Confidence interval, GSI: Global severity index, R: Reference, $\uparrow$ The data were assessed using multiple logistic regression

place of residence. Similarly, in a previous study, researchers reported that depression rates increased after adjusting for the level of education, income, age, and number of pregnancies [unadjusted $\mathrm{OR}=4.19,95 \% \mathrm{CI}=(2.52-6.98)$, adjusted $\mathrm{OR}$ : $5.53,95 \% \mathrm{CI}=(2.09-14.61)]^{(34)}$. How can we explain the higher distress in women living in rural areas? Rural and urban areas exhibit differences in terms of social culture. For instance, in rural areas, infertility is considered a stigma. Therefore, rural couples without children may feel more pressurized about being childless than those who live in cites. Supportive care from healthcare professionals can be effective in avoiding distress after pregnancy loss and during a new pregnancy ${ }^{(40)}$. One of the strengths of our study was the assessment of psychological problems in the two groups at 12 months and more after an abortion and normal delivery. In this period, psychological problems persisted in those with RSA, which provided proof of the need for social support and psychological counseling in this group. The other strong point of our study was the evaluation of psychological distress using the IUS scale, which has never been used in any study in this field.

\section{Study Limitation}

The limitation of our study is that the case sample only included women who had experienced RSA in the first trimester due to the absence of cases of abortion in the second trimester. Therefore, it is suggested that future studies include psychiatric evaluations of women who experience abortion in the second trimester.

\section{Conclusion}

In conclusion, the findings of our study showed that the psychological distress in women with RSA was higher after abortion, it persisted even after one year since the abortion, and it was of greater intensity in women from rural areas. Therefore, it is suggested that women with RSA be provided with psychological counseling to handle the distress they experience. Thus, the psychological management of distress in women with miscarriage must be included in the treatment of RSA.

\section{Acknowledgments}

The authors would like to thank Babol University of Medical Sciences and the participants in this study for their support.

\section{Ethics}

Ethics Committee Approval: This study was approved by the Research Ethics Committee of the Babol University of Medical Sciences (ID: MUBABOL.REC.2015.42).

Informed Consent: All patients signed the free and informed consent form.

Peer-review: External and internal peer-reviewed.

\section{Authorship Contributions}

Surgical and Medical Practices: Z.B., H.A-R., Concept: H.A-R., Z.B., M.F., A.M., Design: H.A-R., Z.B., M.F., A.M., Data Collection or Processing: H.A-R., Analysis or Interpretation: A.B., Literature Search: H.AR., Writing: H.A-R.

Conflict of Interest: No conflict of interest was declared by the authors.

Financial Disclosure: The authors declared that this study received no financial support.

\section{References}

1. Basirat Z, Adib Rad H, Esmailzadeh S, Jorsaraei SG, Hajian-Tilaki K, Pasha H, Ghofrani F. Comparison of pregnancy rate between fresh embryo transfers and frozen-thawed embryo transfers following ICSI treatment. Int J Reprod Biomed (Yazd) 2016;14:39-46.

2. Adib Rad H, Basirat Z, Mostafazadeh A, Faramarzi M, Bijani A, Nouri HR, Soleimani Amiri S. Evaluation of peripheral blood NK cell subsets and cytokines in unexplained recurrent miscarriage. J Chin Med Assoc 2018;81:1065-70.

3. Pasha H, Basirat Z, Esmailzadeh S, Faramarzi M, Adibrad H. Marital Intimacy and Predictive Factors Among Infertile Women in Northern Iran. J Clin Diagn Res 2017;11:QC13-QC17.

4. Volmer L, Rösner S, Toth B, Strowitzki T, Wischmann T. Infertile Partners' Coping Strategies Are Interrelated-Implications for Targeted Psychological Counseling. Geburtshilfe Frauenheilkd 2017;77:52-8.

5. Pasha H, Faramarzi M, Esmailzadeh S, Kheirkhah F, Salmalian H. Comparison of pharmacological and nonpharmacological treatment strategies in promotion of infertility self-efficacy scale in infertile women: A randomized controlled trial. Iran J Reprod Med 2013;11:495-502.

6. Sugiura-Ogasawara M, Ozaki Y, Suzumori N. Management of recurrent miscarriage. J Obstet Gynaecol Res 2014;40:1174-9.

7. Practice Committee of the American Society for Reproductive Medicine. Definitions of infertility and recurrent pregnancy loss: a committee opinion. Fertil Steril 2013; 99:63. 2012/10/26. DOI: 10.1016/j.fertnstert.2012.09.023. 
8. Comba C, Bastu E, Dural O, Yasa C, Keskin G, Ozsurmeli M, et al. Role of inflammatory mediators in patients with recurrent pregnancy loss. Fertil Steril 2015;104:1467-1474.el.

9. Aisenberg Romano G, Ravid H, Zaig I, Schreiber S, Azem F, Shachar $\mathrm{I}$, Bloch M. The psychological profile and affective response of women diagnosed with unexplained infertility undergoing in vitro fertilization. Arch Womens Ment Health 2012;15:403-11.

10. Toffol E, Koponen P, Partonen T. Miscarriage and mental health: results of two population-based studies. Psychiatry Res 2013;205:151-58.

11. Mevorach-Zussman N, Bolotin A, Shalev H, Bilenko N, Mazor M, Bashiri A. Anxiety and deterioration of quality of life factors associated with recurrent miscarriage in an observational study. J Perinat Med 2012;40:495-501.

12. Craig M, Tata P, Regan L. Psychiatric morbidity among patients with recurrent miscarriage. J Psychosom Obstet Gynaecol 2002;23:15764.

13. Sugiura-Ogasawara M, Suzuki S, Ozaki Y, Katano K, Suzumori N, Kitaori T. Frequency of recurrent spontaneous abortion and its influence on further marital relationship and illness: the Okazaki Cohort Study in Japan. J Obstet Gynaecol Res 2013;39:126-131.

14. Lok IH, Neugebauer R. Psychological morbidity following miscarriage. Best Pract Res Clin Obstet Gynaecol 2007;21:229-47.

15. Ladouceur R, Gosselin P, Dugas MJ. Experimental manipulation of intolerance of uncertainty: A study of a theoretical model of worry. Behav Res Ther 2000;38:933-41.

16. Geller PA, Kerns D, Klier CM. Anxiety following miscarriage and the subsequent pregnancy: a review of the literature and future directions. J Psychosom Res 2004;56:35-45.

17. Boivin J, Lancastle D. Medical waiting periods: imminence, emotions and coping. Womens Health (Lond) 2010;6:59-69.

18. Report of a WHO Technical Consultation on Birth Spacing Geneva Switzerland 13-15 June 2005. 2007.

19. Nynas J, Narang P, Kolikonda MK, Lippmann S. Depression and anxiety following early pregnancy loss: recommendations for primary care providers. Prim Care Companion CNS Disord 2015;17(1).

20. Sham Ak, Yiu Mg, Ho Wy. Psychiatric morbidity following miscarriage in Hong Kong. Gen Hosp Psychiatry 2010;32:284-93.

21. Bergner A, Beyer R, Klapp BF, Rauchfuss M. Pregnancy after early pregnancy loss: a prospective study of anxiety, depressive symptomatology and coping. J Psychosom Obstet Gynaecol 2008;29:105-113.

22. Fertl KI, Bergner A, Beyer R, Klapp BF, Rauchfuss M. Levels and effects of different forms of anxiety during pregnancy after a prior miscarriage. Eur J Obstet Gynecol Reprod Biol 2009;142:23-9.

23. Grote NK, Bridge JA, Gavin AR, Melville JL, Iyengar S, Katon WJ. A meta-analysis of depression during pregnancy and the risk of preterm birth, low birth weight, and intrauterine growth restriction. Arch Gen Psychiatry 2010;67:1012-24.

24. Lachmi-Epstein A, Mazor M, Bashiri A. Psychological and mental aspects and" tender loving care" among women with recurrent pregnancy losses. Harefuah 2012;151:633-7, 54.
25. Bhat A, Byatt N. Infertility and perinatal loss: when the bough breaks. Curr Psychiatry Rep 2016;18:31.

26. Li J, Liu B, Li M. Coping with infertility: a transcultural perspective. Curr Opin Psychiatry 2014;27:320-5.

27. Musters AM, Taminiau-Bloem EF, van den Boogaard E, van der Veen F, Goddijn M. Supportive care for women with unexplained recurrent miscarriage: patients' perspectives. Hum Reprod 2011;26:873-7.

28. Rentz AM, Kahrilas P, Stanghellini V, Tack J, Talley NJ, de la Loge $\mathrm{C}$, et al. Development and psychometric evaluation of the patient assessment of upper gastrointestinal symptom severity index (PAGI-SYM) in patients with upper gastrointestinal disorders. Qual Life Res 2004;13:1737-49.

29. Sugiura-Ogasawara M, Nakano Y, Ozaki Y, Furukawa TA. Possible improvement of depression after systematic examination and explanation of live birth rates among women with recurrent miscarriage. J Obstet Gynaecol 2013;33:171-4.

30. Francis K, Dugas MJ, Ricard NC. An exploration of Intolerance of Uncertainty and memory bias. J Behav Ther Exp Psychiatry 2016;52:68-74.

31. Buhr K, Dugas MJ. Investigating the construct validity of intolerance of uncertainty and its unique relationship with worry. J Anxiety Disord 2006;20:222-36.

32. Haghparast E, Faramarzi M, Hassanzadeh R. Psychiatric symptoms and pregnancy distress in subsequent pregnancy after spontaneous abortion history. Pak J Med Sci 2016;32:1097-101.

33. Salmalian H, Nasiri Amiri F, Kheyrkhah F. Prevalence of pre and postpartum depression symptoms and some related factors (Babol; 2006-2007). Journal Of Babol University Of Medical Sciences (Jbums) 2008;10:67-75.

34. Kolte AM, Olsen LR, Mikkelsen EM, Christiansen OB, Nielsen HS. Depression and emotional stress is highly prevalent among women with recurrent pregnancy loss. Hum Reprod 2015;30:777-82.

35. Kagami M, Maruyama T, Koizumi T, Miyazaki K, Nishikawa-Uchida S, Oda H, et al. Psychological adjustment and psychosocial stress among Japanese couples with a history of recurrent pregnancy loss. Hum Reprod 2012;27:787-94.

36. Carleton RN, Duranceau S, Shulman EP, Zerff M, Gonzales J, Mishra S. Self-reported intolerance of uncertainty and behavioural decisions. J Behav Ther Exp Psychiatry 2016;51:58-65.

37. Carleton RN, Mulvogue MK, Thibodeau MA, McCabe RE, Antony MM, Asmundson GJ. Increasingly certain about uncertainty: Intolerance of uncertainty across anxiety and depression. J Anxiety Disord 2012;26:468-79.

38. Talkovsky AM, Norton PJ. Intolerance of uncertainty and transdiagnostic group cognitive behavioral therapy for anxiety. J Anxiety Disord 2016;41:108-14.

39. Broen AN, Moum T, Bødtker AS, Ekeberg O. The course of mental health after miscarriage and induced abortion: a longitudinal, fiveyear follow-up study. BMC Med 2005;3:18.

40. Musters AM, Koot YE, van den Boogaard NM, Kaaijk E, Macklon NS, van der Veen F, et al. Supportive care for women with recurrent miscarriage: a survey to quantify women's preferences. Hum Reprod 2013;28:398-405. 